Original Article

\title{
Role of Paraoxonase-1 (Q192R) Gene Polymorphism in Coronary Artery Disease in Saudi Arabian Population
}

\author{
Samir Abdulkarim Alharbi, Ramprasad Nagarajrao, Abdullah Habbab Alharbi
}

\begin{abstract}
OBJECTIVES: To assess the prevalence and dissemination of PON1 Q192R polymorphism and PON1 activities in CAD patients and controls.

METHODOLOGY: A case control study, conducted from October 2016 to December 2017. Seventy angiographically confirmed Saudi CAD subjects and $\mathbf{5 2}$ healthy individuals were selected in this study. Frequencies of the PON1 gene was done by polymerase chain reaction- restriction fragment length polymorphism technique. Enzyme PON1 activity was estimated by method and using phenyl acetate as substrate. Chi-square and multiple linear regression analyzes was done to determine the odds ratio (OR) for development of CAD.

RESULTS: The PON1 192 RR genotype was observed to be predominant among CAD patients compared to healthy control group members. There was a 2.52 fold increase in the threat of CAD patients in the PON1 RR genotype when contrast to $Q Q$ genotype $(O R=2.520,1.018-6.242)$. Drastically decreased activity of enzyme PON1 was found in CAD patients compared to controls (89.9 vs $128.5 \mathrm{U} / \mathrm{l})$. In the multinomial analysis, the Odds ratio for PON1 192 RR genotype is $2.70, p<0.001$.

CONCLUSION: The study presented that significant relationship among PON1 192 RR genotype and decreased serum PON1 activity might be an effective key risk factor for atherosclerotic heart disease. We suggest that assessing of the PON1 levels can be used as a reliable biochemical marker in the diagnostic tool for cardiovascular disease.
\end{abstract}

KEYWORDS: Paraoxonase-1 gene; Q192R polymorphism; enzyme; PON1 activity; Coronary artery disease

This article may be cited as: Alharbi SA, Nagarajrao R, Alharbi AH. Role of Paraoxonase-1 (Q192R) Gene Polymorphism in Coronary Artery Disease in Saudi Arabian Population. J Liaquat Uni Med Health Sci. 2019;18(01):34-41. doi: 10.22442/jlumhs.191810598

\section{INTRODUCTION}

Coronary artery disease is a paradigmatic complex disorder caused by multiple physiologic, genetic and environmental factors ${ }^{1}$. CAD is still considered a worldwide leading cause of mortality in developing nations. As per appraises by the WHO, approximately 7 million peoples globally die of heart disease every year in both men and women, with most of these deaths occurring in both high- and low- income countries. In the course of recent years, CAD has turned to be the chief cause of fatality in the Kingdom of Saudi Arabia (KSA) and has reached pandemic proportions ${ }^{2}$.

Atherosclerosis is an inflammatory disease ${ }^{3}$, characterized by the accumulation of lipids and fibrous elements in the large arteries, with oxidative stress as a primary contributing factor. According to "response to retention hypothesis," the entire sequence of events is found to be initiated by the retention of modified low - density lipoprotein ${ }^{4}$. The oxidative modifications of LDL-c in the endothelial wall might be a significant factor in the development of atherosclerotic plaques.
So many studies ${ }^{5}$ recommended that LDL act as a major incident in the genesis of atherosclerosis.

Epidemiological, pharmacological, genetic, and clinical studies $^{6}$ implicated that the development of atherosclerosis is closely associated with a lot of extraneous and inherent risk factors, including age, hypertension, obesity, lack of exercise, smoking, type 2 diabetes and dyslipidemia have been identified. Several authors ${ }^{7}$ have demonstrated that improvement and progress of CAD are related to free radical processes. Lipid peroxidation is the oxidative degradation of lipids, which is potentially harmful because its uncontrolled, self-enhancing process causes disruption of membranes and other cell components ${ }^{8}$. Thus observing of lipids and lipid peroxidation in the blood is a valuable source for the forecast of CAD cases.

Human serum Paraoxonase 1 is a protein of 355 amino acids ( $44 \mathrm{kDa})$, and the genes are situated on the chromosome $7(7 q 21-22)$. It is a calciumdependent serum esterase that mainly synthesized in the liver, which is tightly attached to HDL particles that catalyzes the hydrolyzsis of various extremely 
harmful xenobiotics 9 . PON1 has become the central subject of both on phenotypic and genotypic levels succeeding to the recognition of its antioxidant functions, mainly to secure LDL from oxidative injury ${ }^{10}$. Numerous prospective studies ${ }^{11}$ have shown that Q192R (rs662) polymorphism in the coding region of the gene is an amino acid exchange glutamine ( $Q$ ) to arginine (R) substitutions at position 192 in the A575G region. Moreover, $Q(\mathrm{GIn})$ and $\mathrm{R}(\mathrm{Arg})$ alleles at the 192 loci of the PON1 codon have been associated with enzyme concentration and activity respectively. The QQ- genotype displays a low PON movement, while RR- genotype shows a high PON action. Conversely, there is additionally noticeable difference in enzyme activity among individuals of the similar genotype $^{12}$. PON1 position $192 \mathrm{R}$ isoform binds with HDL-c with a three - fold lesser affinity than the $Q$ isoenzyme and subsequently displays lower firmness, lapolactonase, and arylesterase activity. It has been recommended that the allele $Q$, which is richer than the allele $R$, in charge of the defensive against coronary atherosclerosis, meanwhile the allele $\mathrm{R}$ has been identified with CAD because of less protection against LDL. These distinctions in the properties of PON1 $192 \mathrm{Q} / \mathrm{R}$ isoenzyme give the basis for the role of PON1 $192 \mathrm{Q} / \mathrm{R}$ polymorphism to the susceptibility to atherosclerosis ${ }^{13}$. So many authors revealed that PON1 Q192R polymorphism is an important risk for $\mathrm{MI}$ and CAD populations ${ }^{14,15}$. Contrastingly, some studies reported that no such relationship among Q192R polymorphism and an elevated atherosclerosis risk $^{16}$. Moreover, several studies have shown that it is essential to decide the phenotype, not only the genotype, when examining the atherosclerosis ${ }^{17,18}$. Hence, in this present study we assessed the lipid profile, lipid peroxidation product MDA, the dissemination and occurrence of PON1 gene polymorphism and the enzyme PON1 activity was analyzed in patients of CAD and healthy individuals in the central province of Saudi Arabian population.

\section{METHODOLOGY}

A case-controlled study was taken during the period of October 2016 to December 2017. The study patients were all admitted in the intensive coronary care unit or attending to the medicine ward of the Al-Quwayiyah General Hospital, Saudi Arabia.

The study group consisted of angiographically identified $70 \mathrm{CAD}$ patients and they were enrolled to hospital and they were between 40 and 65 years of ages among both the genders (41 Males and 29 Females). Fifty two healthy volunteers, both age and gender matched who were non CAD subjects were considered as controls. Information of age, sex, socio-demographic characteristics, personal and familial medical history was taken through a standard questionnaire.

The inclusion criteria for finding the CAD were made in view of clinical history, severe chest pain, 12 drives electrocardiogram, echocardiography and coronary angiography findings. Blood pressure was measured as recommended by the American Diabetic Association ${ }^{19}$. We considered whose BMl was $>30 \mathrm{~kg} /$ $\mathrm{m}^{2}$ as obesity ${ }^{20}$.

The exclusion criteria were include subjects suffering from diabetes mellitus, renal disease, hepatic infection, strokes, pregnancy, cerebrovascular accidents and patients taking any sort of multivitamins or antioxidant drugs were excluded from the study.

\section{Collection of blood samples and biochemical measurements}

Trained nurses collected $4 \mathrm{ml}$ of blood and $4 \mathrm{ml}$ of Ethylenediamine tetraacetic acid (EDTA) blood from every participant. Blood samples were centrifuged at $4000 \mathrm{rpm}$ for 6 minutes; the plasma was carefully transferred to plain vacuntainers for measuring the biochemical parameters i.e. total cholesterol, triglycerides, LDL-C, and HDL-c levels were measured by standard enzymatic methods using a fully automated analyzer (Cobas Integra 800 plus, ROCHE diagnostics, Germany). EDTA samples were used for gene polymorphism analysis. A marker of lipid peroxidation i.e. MDA levels were calculated by thiobarbutric acid (TBA) method ${ }^{21}$.

\section{Estimation of PON-1 activity}

PON-1 activity was estimated by using phenyl acetate as a substrate. The working reagent consists of by adding $100 \mu \mathrm{l}$ of serum to $2 \mathrm{ml}$ of Tris/ HCL buffer (150 mmol/l, pH 7.5) contain $2 \mathrm{mmol} / \mathrm{l}$ calcium chloride, $150 \mu \mathrm{l}$ of $15 \mathrm{mmol} / \mathrm{l}$ phenyl acetate and 150 $\mu \mathrm{l}$ of serum sample is diluted (1: 5 diluted by distilled water). Preliminary rates of hydrolysis were dictated by subsequent rise of the concentration of phenol at $270 \mathrm{~nm}$ at $25^{\circ} \mathrm{C}$. Enzymatic activity was expressed in Units/Litre ${ }^{22}$.

DNA extraction and molecular analysis of gene polymorphism

Genomic DNA was extracted from the peripheral blood by using salting out procedure (QIAGEN, DNA isolation kit QIAamp from Germany). DNA samples were preserved at $-80^{\circ} \mathrm{C}$ until needed for analysis.

The Q192R variant of the PON1 gene was detected by using a PCR restriction fragment length polymorphism (RFLP) assay ${ }^{23}$. In template region or coding region of PON1 gene Q192R polymorphism including the sense sequence 5' TAT TGA ACC GGA AAA CCT TGC G- 3'and antisense sequence 5' CAC AAA GTG TGA CGG TTC TGT C- 3'. Genomic DNA $(5 \mu \mathrm{g})$ was amplified in $25 \mu \mathrm{l}$ reaction mixture 
containing $0.4 \mu \mathrm{mol} / \mathrm{l}$ of each primer and red dye master mix (Bangalore Genei, India) containing 100 $\mu \mathrm{mol} / \mathrm{l}$ of each dNTP, $25 \mu \mathrm{l}$ of $10 \mathrm{x}$ reaction buffer and 0.6 units of Taq DNA polymerase. Thermal cycling was as follows: The DNA was denatured at $95^{\circ} \mathrm{C}$ for 5 minutes followed by 45 cycles; each consisting of denaturation at $92^{\circ} \mathrm{C}$ for 34 seconds, 32 seconds of annealing at $60^{\circ} \mathrm{C}$ and 45 seconds of extension at $72^{\circ} \mathrm{C}$. The reaction was completed with a final extension at $72^{\circ} \mathrm{C}$ for 10 minutes. PON1 polymorphism was detected by digestion of the PCR amplified product with the $\mathrm{A} 1 \mathrm{wl}$ restriction enzyme (one unit for 2 hours) and resolved by size fractionation in $12 \%$ native polyacrylamide gel. The genotype QQ (glutamine) was detected by the presence of single 165 base pair fragments, and genotype RR (arginine) was found out by the occurrence of 120 and 48 base pair fragments, while the QR (glutamine/arginine) genotype was recognized by the occurrence of 165,120 and 48 base pair fragments were observed (Figure I).

This research work was permitted by the institutional ethical committee and scientific research panel of college of applied medical sciences, Shaqra University, KSA. Written informed permission was also taken from all participants of the study.

The analyzed detailed results were presented as mean \pm standard error. Chi-square $\left(X^{2}\right)$ test and student's $t$-test were used for the assessment between the groups of the categorical and continuous variables. Allele frequencies were calculated by allele counting. Genotype and allele frequencies were measured by $X^{2}$ test, Odds ratio and $95 \%$ confidence intervals (Cls) were designed by binominal linear regression. The disseminations of allele and genotype frequencies were calculated from Hardy- Weinberg equilibrium. The comparison of three genotypic groups for the different variables was evaluated by One- way analysis of variance. Multinomial logistic regression analysis was done to determine the communication between human PON1 genotype variants and lipid profile parameters in relation to the prevalence of CAD. We used SPSS windows version 23.0 (SPSS, Cary, NC) for the statistical information. All $p$-values equal or $<.05$ was considered statistically significant.

\section{RESULTS}

\section{Clinical and biochemical characteristics}

The demographical and clinical attributes of controls and CAD patients are exhibited in Table I. The age, $B M I, S B P$ and DBP were significantly higher in CAD groups as compared to healthy subjects. The biochemical parameters like TC, TG, LDL- $c$ and stress marker MDA levels were increased in CAD patients. In contrast, significantly decreased levels of HDL- $c$ and PON-1 activities in patients than in the healthy controls $(p<0.001)$.

\section{Molecular analysis of Q192R polymorphism and distribution of allele}

The frequencies of Q192R genotypes were as follows; QQ $(25.7 \%)$, QR $(42.9 \%)$ and $R R(31.4 \%)$ in patients and $Q Q(40.4 \%), Q R(44.2 \%)$ and $R R(15.4 \%)$ in controls respectively. A comparative analysis revealed that there was a considerable increase of RRgenotype frequency and decreased percentage of $Q Q$ - genotype in CAD subject's compared to controls. Whereas, in QR genotype slightly increased in controls when compared to CAD cases. The frequencies of alleles ( $Q$ and $R$ ) among the controls and patients are presented in Table 2. The ORs for $\mathrm{QQ}$ is $0.564(95 \% \mathrm{Cl}: 0.261-1.282, p<0.137)$ and $2.520(95 \% \mathrm{Cl}: 1.018-6.242, p<0.045)$ for RRgenotype respectively. The significantly increased frequencies of PON1 $192 \mathrm{R}$ allele in CAD group when compared to controls $(\mathrm{OR}=2.096,1.248-3.528$, $p<0.004)$. Whereas $Q$ allele ORs $=0.476(95 \% \mathrm{Cl}$ : 0.284-0.801), respectively. These above results indicate that RR- genotype has increased risk of developing CAD.

\section{Characteristics of Q192R genotype distribution in different parameters}

The dispersion of anthropometric and biochemical variables found on the different genotypes (QQ, $Q R$ and $R R$ ) in the CAD patients. We observed that RRgenotypes in combination with $Q Q$ and $Q R$ genotypes were significantly associated with slightly increased in TC, TG, LDL-c and MDA levels $(p<0.05)$. Conversely in Table III, the RR- genotype was found remarkably lowered HDL-c $(35.4 \pm 3.9, p<0.015)$ and PON1 activity levels $(68.5 \pm 11.5, p<0.002)$ when compared to that of $\mathrm{QQ}$ and $\mathrm{QR}$ genotypes.

\section{Multinomial analysis}

Linear regression analysis was carried out for PON1 Q192R genotypes and various risk factors like age, gender, BMI, and blood pressure appeared as confounding variables. The significant $p$ value for lipids, MDA, PON1 activity and PON1 gene polymorphism indicates that alternation in these parameters will affect the risk of CAD as presented in Table IV. The negative $\beta$ value for enzyme PON1 and levels of HDL-C shows that decrease of these parameters will enhance the risk of CAD. Association of $Q R(O R=1.358,95 \% \mathrm{Cl}: 0.601-2.683, p<0.003)$ and $\mathrm{RR}(\mathrm{OR}=2.706,1.001-.839, p<0.001)$ genotypes with disease stays outstanding for developing coronary atherosclerosis. 


\section{FIGURE I: POLYMERASE CHAIN REACTION - RESTRICTION FRAGMENT LENGTH POLYMORPHISM (PCR- RFLP) OF PON1 GENE}

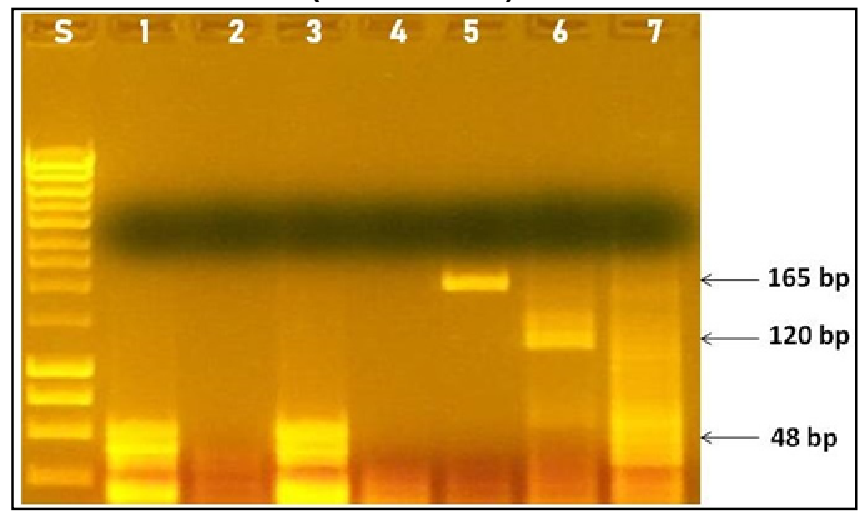

Lane S: DNA molecular standard marker 25 - 450 bp Lane 1,3,6: RR genotype (Homozygous) (48, $120 \mathrm{bp})$ Lane 5: QQ genotype (Homozygous) (165 bp) Lane 7: QR genotype (Heterozygous) $(165,120,48$ bp)

TABLE I: DEMOGRAPHIC AND CLINICAL DATA OF THE HEALTHY CONTROLS AND CAD PATIENTS

\begin{tabular}{|l|r|r|r|}
\hline \multicolumn{1}{|c|}{ Parameters } & \multicolumn{1}{c|}{$\begin{array}{c}\text { Controls } \\
(\boldsymbol{n}=\mathbf{5 2})\end{array}$} & \multicolumn{1}{c|}{\begin{tabular}{c}
\multicolumn{1}{c|}{ CAD } \\
$(\boldsymbol{n}=\mathbf{7 0})$
\end{tabular}} & ${ }^{*} \boldsymbol{p}$ value \\
\hline Age (yrs) & $49.3 \pm 8.8$ & $53.1 \pm 9.7$ & 0.041 \\
\hline $\begin{array}{l}\text { Gender } \\
\text { (male - female) }\end{array}$ & $28-24$ & $41-29$ & 0.372 \\
\hline BMl (kg / m $\left.{ }^{2}\right)$ & $25.3 \pm 2.6$ & $29.1 \pm 2.2$ & 0.030 \\
\hline SBP (mmHg) & $120.8 \pm 3.2$ & $134.5 \pm 4.0$ & 0.021 \\
\hline DBP (mmHg) & $80.1 \pm 3.0$ & $87.2 \pm 3.8$ & 0.028 \\
\hline $\begin{array}{l}\text { Family history of } \\
\text { CAD (\%) }\end{array}$ & -- & $27 \%$ & 0.023 \\
\hline $\begin{array}{l}\text { Total cholesterol } \\
\text { (mg/dl) }\end{array}$ & $160.2 \pm 10.0$ & $209.2 \pm 11.1$ & 0.012 \\
\hline $\begin{array}{l}\text { Triglycerides } \\
\text { (mg/ dl) }\end{array}$ & $80.2 \pm 9.8$ & $158.5 \pm 12.4$ & 0.066 \\
\hline HDL-C (mg/ dl) & $58.6 \pm 7.7$ & $41.1 \pm 8.7$ & 0.022 \\
\hline LDL-C (mg/ dl) & $90.4 \pm 12.1$ & $178.9 \pm 13.8$ & 0.061 \\
\hline MDA (nmoles/ml) & $3.89 \pm 1.1$ & $7.11 \pm 1.6$ & 0.010 \\
\hline PON1 (U / L) & $128.5 \pm 14.2$ & $89.9 \pm 17.3$ & 0.001 \\
\hline
\end{tabular}

Data are represented as the mean $\pm S D$; $B M I$ : Body mass index, SBP: Systolic blood pressure, DBP: Diastolic blood pressure.

Comparisons were made by using students ' $t$ ' test. ${ }^{*} p<0.05$, indicates statistically significant, between the patients and controls.
TABLE II: THE ALLOCATION AND OR OF GENOTYPES AND ALLELE FREQUENCIES OF THE HUMAN PON1 GENE Q192R POLYMORPHISM IN CONTROLS AND CAD PATIENTS

\begin{tabular}{|l|c|c|c|c|}
\hline $\begin{array}{l}\text { Q192R gene } \\
\text { polymorphism }\end{array}$ & $\begin{array}{c}\text { Controls } \\
(\boldsymbol{n}=\mathbf{5 2})(\%)\end{array}$ & $\begin{array}{c}\text { CAD } \\
(\boldsymbol{n}=\mathbf{7 0}) \\
(\%)\end{array}$ & $\begin{array}{c}\text { OR } \\
(\mathbf{9 5} \% \mathrm{Cl})\end{array}$ & $\boldsymbol{p}$ value \\
\hline $\begin{array}{l}\text { Genotype } \\
\text { QQ }\end{array}$ & $21(40.4)$ & $18(25.7)$ & $\begin{array}{c}0.564 \\
(0.261-1.282)\end{array}$ & 0.137 \\
\hline QR & $23(44.2)$ & $30(42.9)$ & $\begin{array}{c}0.945 \\
(0.458-1.949)\end{array}$ & 0.879 \\
\hline RR & $08(15.4)$ & $22(31.4)$ & $\begin{array}{c}2.520 \\
(1.018-6.242)\end{array}$ & 0.045 \\
\hline $\begin{array}{l}\text { Allele } \\
\text { Q }\end{array}$ & $65(62.5)$ & $62(44.3)$ & $\begin{array}{c}0.476 \\
(0.284-0.801)\end{array}$ & 0.005 \\
\hline R & $39(37.5)$ & $78(55.7)$ & $\begin{array}{c}2.096 \\
(1.248-3.528)\end{array}$ & 0.004 \\
\hline
\end{tabular}

The $X^{2}$ test was used for distribution and comparison of genotypes and alleles frequency of PON1 Q192R gene polymorphism. Cl: confidence interval, $p<0.05$.

\section{TABLE III: DISTRIBUTION OF CAD PATIENTS CHARACTERISTICS ACCORDING TO ANTHROPOMETRIC AND METABOLIC PARAMETERS IN PON1 Q192R GENOTYPES}

\begin{tabular}{|l|r|r|r|r|}
\hline Parameters & \multicolumn{1}{|c|}{$\mathbf{Q Q}$} & \multicolumn{1}{c|}{$\mathbf{Q R}$} & \multicolumn{1}{c|}{$\mathbf{R} \mathbf{R}$} & \multicolumn{1}{c|}{$\begin{array}{c}\text { * } \boldsymbol{p} \\
\text { value }\end{array}$} \\
\hline Age (yrs) & $48.2 \pm 10.2$ & $50.3 \pm 8.9$ & $52.9 \pm 7.7$ & 0.670 \\
\hline $\begin{array}{l}\text { Gender (Male } \\
\text { - Female) }\end{array}$ & $10-08$ & $14-10$ & $19-09$ & 0.421 \\
\hline BMl (kg / m²) & $25.9 \pm 2.2$ & $26.3 \pm 2.0$ & $28.9 \pm 3.3$ & 0.214 \\
\hline SBP (mmHg) & $122.3 \pm 6.9$ & $128.8 \pm 7.3$ & $127.3 \pm 8.7$ & 0.348 \\
\hline DBP (mmHg) & $80.1 \pm 5.5$ & $83.3 \pm 6.3$ & $84.1 \pm 6.0$ & 0.720 \\
\hline $\begin{array}{l}\text { Family history } \\
\text { of CAD (\%) }\end{array}$ & $30 \%$ & $38 \%$ & $32 \%$ & 0.503 \\
\hline $\begin{array}{l}\text { Total choles- } \\
\text { terol (mg/dl) }\end{array}$ & $186.2 \pm 16.1$ & $201.3 \pm 19.3$ & $210.8 \pm 18.7$ & $0.043 *$ \\
\hline $\begin{array}{l}\text { Triglycerides } \\
\text { (mg/ dl) }\end{array}$ & $149.3 \pm 13.2$ & $156.3 \pm 14.2$ & $158.2 \pm 17.7$ & 0.068 \\
\hline $\begin{array}{l}\text { HDL-C (mg/ } \\
\text { dl) }\end{array}$ & $40.1 \pm 3.3$ & $36.8 \pm 4.1$ & $35.4 \pm 3.9$ & $0.015 *$ \\
\hline $\begin{array}{l}\text { LDL-C (mg/ } \\
\text { dl) }\end{array}$ & $135.3 \pm 9.2$ & $140.8 \pm 8.9$ & $142.9 \pm 10.2$ & $0.041 *$ \\
\hline $\begin{array}{l}\text { MDA (nmoles/ } \\
\text { ml) }\end{array}$ & $6.9 \pm 3.0$ & $7.4 \pm 2.9$ & $7.8 \pm 2.7$ & $0.051 *$ \\
\hline PON1 (U / L) & $86.3 \pm 11.0$ & $75.8 \pm 10.8$ & $68.5 \pm 11.5$ & $0.002 *$ \\
\hline
\end{tabular}

${ }^{*} p<0.05$ indicates a statistically significant difference, between RR and QR / QQ genotypes. 
Samir Abdulkarim Alharbi, Ramprasad Nagarajrao, Abdullah Habbab Alharbi

TABLE IV: MULTIPLE LINEAR REGRESSION ANALYSIS OF THE RELATIONSHIP OF PON1 Q192R POLYMORPHISM WITH CAD RISK

\begin{tabular}{|l|r|r|r|c|}
\hline \multicolumn{1}{|c|}{ Parameters } & \multicolumn{1}{c|}{$\boldsymbol{\beta}$} & \multicolumn{1}{c|}{ SE } & OR (95 \% Cl) & $\boldsymbol{P}$ value \\
\hline Age $(\mathrm{yrs})$ & 0.061 & 0.312 & $1.016(0.662-1.428)$ & 0.871 \\
\hline Gender (male vs female) & 0.208 & 0.467 & $1.322(0.560-2.136)$ & 0.610 \\
\hline BMl $\left(\mathrm{kg} / \mathrm{m}^{2}\right)$ & 0.313 & 0.263 & $1.254(0.501-2.018)$ & 0.586 \\
\hline SBP $(\mathrm{mmHg})$ & 0.420 & 0.221 & $1.481(0.861-3.115)$ & 0.738 \\
\hline DBP $(\mathrm{mmHg})$ & 0.289 & 0.302 & $1.368(0.611-2.564)$ & 0.639 \\
\hline Family history of CAD (\%) & 0.825 & 0.322 & $1.571(0.730-2.869)$ & 0.240 \\
\hline Total cholesterol $(\mathrm{mg} / \mathrm{dl})$ & 2.212 & 0.711 & $1.282(0.837-2.198)$ & 0.033 \\
\hline Triglycerides $(\mathrm{mg} / \mathrm{dl})$ & 1.982 & 0.683 & $1.306(0.719-2.646)$ & 0.041 \\
\hline HDL-C (mg/ dl) & -0.981 & 0.538 & $0.589(0.325-0.982)$ & 0.002 \\
\hline LDL-C (mg/ dl) & 2.011 & 0.730 & $1.413(0.802-2.869)$ & 0.047 \\
\hline MDA (nmoles/ml) & 2.812 & 0.922 & $1.321(0.621-2.834)$ & 0.010 \\
\hline PON1 (U/L) & -1.013 & 0.389 & $0.452(0.180-0.728)$ & 0.001 \\
\hline Q192R polymorphism QR & 0.832 & 0.267 & $1.358(0.601-2.683)$ & 0.003 \\
\hline RR & 1.453 & 0.392 & $2.706(1.011-5.839)$ & 0.001 \\
\hline${ }^{*} p<0.05$ value indicates a statistically significant, $\beta$ coefficient, SE standard error. & \\
\hline
\end{tabular}

\section{DISCUSSION}

Several researchers observed the theory that lesser activity of serum PON1 associated with a rise in plaque formation with an elevated cause of $C A D^{24}$. The results of the Caerphilly study, the first potential epidemiological study of PON1 and CAD, also showed that activity of serum PON1 anticipate the coronary proceedings independent of all other coronary threat factors, as well as $\mathrm{HDL}^{25}$. Moreover, a recent study from Chandrasekaran $S 2016^{26}$ and Tan $Y$ et $a l^{27}$ supports the theory that lesser PON1 activity in the development of atherosclerosis. In contrast, in an Iranian $^{28}$ and Indian case- control studies ${ }^{29}$ showed that no differences occur in PON1 activity in CAD patients and healthy individuals. The current evidence showed that there are a significant decreased level of enzyme PON1 activities in cardiac patients than in the controls $(89.9 \pm 17.3$ vs $128.5 \pm 14.2, p<0.001)$. The reason for this incident is that the enzyme active site sulfhydryl group is observed to be vital for its aryl esterase and peroxidase activity and this group gets oxidized during its movement against oxidized LDL. So many authors revealed that it is an important that serum PON1 activity and its concentration also be considered in adding to gene polymorphism as assessing its relationship with $C A D^{30}$.

In the current study, we examined the possibility of PON1 gene polymorphism is proatherogenic and it could provide valuable information in anticipating CAD status in Saudi Arabian individuals. So many studies found a relationship between different polymorphism of the PON1 genes against the disease ${ }^{31,32}$. The superior relationship was observed by specially reporting a defensive part of the Q192 allele and a harmful impact of the R192 allele in PON1 Q192R polymorphism ${ }^{18}$. The outcome of the current study in controls shows that incidence of the Q192 allele is superior then R192 allele $(62.5 \%$ and $37.5 \%$, respectively). The similar incidence of the alleles was closely observed in different countries ${ }^{10,17,33}$ but differed from the Chinese and Hispanic populations ${ }^{34,35}$. It is very clear that there are different reports by sharing of alleles which was consider to their greater or lesser allele in different ethnic populations.

Numerous studies revealed that there is a vast relationship between the PON1 $192 \mathrm{R}(\mathrm{Arg})$ allele in the progress of $C A D^{36,26}$. Zama $T$ et $a l^{37}$ from Japan described that, the occurrence of PON $1192 \mathrm{R}$ allele was notably related with CAD possibility even though controlling for a risk factor. Moreover, Turban $\mathrm{S}$ et $\mathrm{al}^{\beta 8}$, from American and Birjmohun RS et al ${ }^{16}$, from Caucasian found that there is no association between CAD disease and Q192R polymorphism. The current study, observed that significantly superior frequency of RR- genotype $(31.4 \%)$ has a higher risk in CAD compared to controls (15.4\%) respectively. Our study also shows positive correlation between the RR genotypes of PON1 gene polymorphism in CAD individuals compare to controls $(95 \% \mathrm{Cl}$ : 1.108 6.242, $\quad \mathrm{OR}=2.520, \quad p<0.045)$, because $\mathrm{RR}$ polymorphism gives the most minimal defense against 
HDL oxidation and LDL compare to different polymorphisms.

We also observed the allocation of confounding variables in CAD patients according to Q192R genotype. Interestingly, our present information showed that CAD patients having the RR and $Q R$ genotypes have drastically increased levels of TC, TG, LDL and reduced levels of HDL- $c$ and PON1 activity when compared to $Q Q$ genotype. These above outcomes are in concurrence with Hassan MA et $a l^{10}$, who confirmed that PON1 polymorphism affects the lipid profiling in CAD disease. Furthermore, Ombres $D$ et $a l^{\beta 9}$ exposed that the $192 \mathrm{QQ}$ genotype is related to less atherogenic lipid profile and also it was determined that reduced shifting of lipids, which are related to lower serum PON1 activity alleles. So many studies revealed that high concentration of MDA in CAD patients ${ }^{8}$. In the current study, significant increase of MDA concentration was seen in CAD group versus healthy subjects $(7.1 \pm 1.5$ vs $3.89 \pm 1.1)$ respectively. We also observed that the individual of RR genotypes had higher levels of serum MDA than the $Q R$ and $Q Q$ genotypes $(p<0.051)$. Similar results were seen in North African population study ${ }^{17}$.

$A$ recent case control study, observed that $R R$ and $Q R$ genotypes having a significant low serum PON1 activity compared to $Q Q$ genotype ${ }^{17}$. We also detected that the low PON1 activity was related with all three PON1 genotypes. There was a noteworthy low PON1 activity among in RR genotypic individuals $(68.5 \pm 11.5)$ when compared to QR $(75.8 \pm 10.8)$ and $Q Q$ $(86.3 \pm 11.0)$ genotypes $(p<0.002)$. The possible mechanism for replacement of glutamine by arginine in $192^{\text {nd }}$ position reduces the affinity of $\mathrm{N}$ - terminal amphipathic helix of PON enzyme with HDL thereby the enzyme gets destabilized and the activity is lowered $^{26}$.

Finally, we carried out multiple linear regression analysis of PON1 gene polymorphism and the confounding variables. The significant $p$ value for HDL, LDL, MDA, PON1 activity and PON1 gene polymorphism ( $Q R$ and $R R$ genotype) indicates that alteration of these parameters will affect the risk of CAD disease. Whereas interestingly, the odds ratio of developing CAD were increased close to 2.706 - fold in the RR genotypes compared to healthy controls in Saudi populations. Our results were similar with recent findings of Saudi Arabian, North African and South Indian studies which also reported that CAD with RR genotype has more than 2 to 3 fold risk of developing coronary arthrosclerosis ${ }^{10,17,26}$.

Human epidemiological and experimental studies give persuading confirmation that PON plays a very vital role in defense against atherosclerosis ${ }^{40}$. So, the measuring of serum PON1 is a useful informative in anticipating upcoming CAD risk. It is also very important to advise that utilizing of enzyme PON1 activity in the diagnostic laboratories as a best indicator for the cardiovascular disease patients.

The present study had several limitations; study cohorts were moderately little for both cases and controls. We recommend that it is necessary to conduct large cohort studies on this additional genetic polymorphism, haplotypes, and other genes that might be related to PON1 gene function.

\section{CONCLUSION}

This will be the first report to measure PON1 Q192R polymorphism in CAD disease among the Saudi inhabitants in Central province (Al- Quwayiyah region) of Saudi Arabia. The study presented that significant involvement was observed in RR genotype of the PON1 polymorphism and decreased serum PON1 activity may be a potent independent risk factor for coronary atherosclerosis in Saudi populations and suggesting that it could have predictive importance. We anticipate that the PON1 is an imperative enzyme in oxidant - antioxidant status of atherosclerosis with its antioxidant effect. Therefore, assessing of enzyme PON1 activity can be used as an exceptional marker in diagnostic tool for cardiovascular diseases.

\section{ACKNOWLEDGMENTS}

We thank every staffs of the Al-Quwayiyah general hospital and especially for the staff of the medicine, ICCU and diagnostic ward.

\section{CONFLICT OF INTEREST: None}

\section{REFERENCES}

1. InanooRahatloo $\mathrm{K}$, Parsa AFZ, Huze $\mathrm{K}$, Rasooli $\mathrm{P}$, Davaran S, Platzer M, et al. Mutation in ST6GALNAC5 identified in family with coronary artery disease. Scientific Reports. 2014; 4: 3595. doi: 10.1038/srepo3595.

2. Cyrus C, Vatte C, Al-Nafie A, Chathoth S, Al-Ali R, Al-Shehri A, et al. The impact of common polymorphisms in CETP and ABCA1 genes with the risk of coronary artery disease in Saudi Arabians. Human Genomics. 2016;10:8. doi: 10.1186/s40246- 0160065-3.

3. Cristiano F, Martina M. Atherosclerosis is an inflammatory disease which lacks a common anti inflammatory therapy: How human genetics can help to this issue. A narrative review. Front Pharmacol. 2018; 9: 55 . doi: 10.3389/ fphar.2018.00055.

4. Craig SR, Amin RV, Russell DW, Paradise FN. Blood cholesterol screening. J Gen Intern Med. 2000; 15(6): 395-399.

5. Steinberg D. Low density lipoprotein oxidation and 
its pathobiological significance. J Biol Chem. 1997; 272 (34): 20963-66.

6. Rad EM, Assadi F. Management of hypertension in children with cardiovascular disease and heart failure. Int J Prev Med. 2014; 5(1):S10-S16.

7. Pavlova LE, Savov VM, Petkov HG, Charova IP. Oxidative stress in patients with beta thalassemia major. Prilozi. 2007; 28(1):145-154.

8. Rao RN. Study of trace elements and malondialdehyde levels in cardiovascular disease patients. Int J Adv Res Biol Sci. 2014; 1(9):25-32.

9. Fridman O, Gariglio L, Riviere S, Porcile R, Fuchs $A$, Potenzoni $M$. Paraoxonase 1 gene polymorphism and enzymes activities in coronary artery disease and its relationship to serum lipids and glycemia. Arch Cardiol Mex. 2016; 86(4):35057. doi: 10.1016/j.acmx.2016.08.001.

10. Hassan MA, Al-Attas OS, Husssain T, Al-Daghri NM, Alokail MS, Mohammed Ak, et al. The Q192R polymorphism of the paraoxonase 1 gene is a risk factor for coronary artery disease in Saudi subjects. Mol Cell Biochem. 2013; 380(1-2): 121-28. doi: 10.1007/s11010-013-1665-z.

11. Ko YL, Ko YS, Wang SM, Hsu L, Chang C, Chu P, et al. The Gln- Arg 191 polymorphism of the human PON gene is not associated with the risk of coronary artery disease among Chinese in Taiwan. Atherosclerosis 1999; 141(2):259-64.

12. Humbert R, Adler DA, Disteche CM, Hassett $C$, Omiecinski CJ, Furlong CE. The molecular basis of the human paraoxonase activity polymorphism. Nat Genet. 1993; 3(1):73-76.

13. Gaidukov L, Rosenblat M, Aviram M, Tawfik DS. The $192 \mathrm{R} / \mathrm{Q}$ polymorphs of serum paraoxonase PON1 differ in HDL binding, lipolactonase stimulation, and cholesterol efflux. J Lipid Res. 2006; 47(11): 2492-2502.

14. Mendonca MI, Dos Reis RP, Freitas AI, Pereira A, Sousa A, Freitas $S$, et al. Interaction of paraoxonase - 192 polymorphism with low HDL cholesterol in coronary artery disease risk. Rev Port Cardiol. 2010; 29(4):571-80.

15. Ahmad I, Narang R, Venkatraman A, Das N. Twoand three locus haplotypes of the paraoxonase (PON1) gene are associated with coronary artery disease in Asian Indians. Gene. 2012; 506(1):24247. doi: 10.1016/j.gene.2012.06.031.

16. Birjmohun RS, Vergeer M, Stroes ES, Sandhu MS, Ricketts SL, Tanck MW, et al. Both Paraoxonase-1 genotype and activity do not predict the risk of future coronary artery disease; the EPIC- Norfolk prospective population study. PLoS ONE. 2009; 4(8): e6809. doi: 10.1371/ journal.pone.0006809.

17. Bounafaa A, Berrougui H, Ghalim N, Nasser B,
Bagri A, Moujahid A, et al. Association between Paraoxonase 1 (PON1) polymorphisms and the risk of acute coronary syndrome in a North African population. PLoS ONE. 2015; 10(8): e0133719. doi: 10.1371/journal.pone.0133719.

18. Mackness B, Davies GK, Turkie W, Lee E, Roberts DH, Hill E, et al. Paraoxonase status in coronary heart disease: are activity and concentration more important than genotype? Arterioscler Thromb Vasc Biol. 2001; 21(9):1451-57

19. Ian HD, Sripal B, Athanase B et al. Diabetes and hypertension: A position statement by the American diabetes association. Diabetes Care. 2017; 40(9):1273-84. doi:10.2337/dci17-0026.

20. Frank FQ. Body Mass Index: Obesity, BMI, and Health: A critical Review. Nutr Today. 2015; 50 (3):117-128.

21. Yagi K. Lipid peroxides and Human diseases. Chem Phys Lipids. 1987; 45(2-4):337-51.

22. Haagen L, Brock A. A New Automated Method for Phenotyping Arylesterase (EC 3.1.1.2) based upon inhibition of Enzymatic Hydrolysis of 4Nitrophenyl Acetate by Phenyl Acetate. Eur J Clin Chem Clin Biochem. 1992; 30(7): 391-5.

23. Martinez-Quintana E, Rodriguez-Gonalez F, Medina-Gil JM, Garay-Sanchez P, Tugores A. Paraoxonase 1 (Q192R) gene polymorphism, coronary heart disease and the risk of a new acute coronary event. Clin Investig Arterioscler. 2017; 29 (1):1-6. doi: 10.1016/j.arteri.2016. 07.005.

24. Jayakumari N, Thejaseebai G. High prevalence of low serum paraoxonase-1 in subjects with coronary artery disease. $\mathrm{J}$ Clin Biochem Nutr. 2009; 45(3):278-84.

25. Mackness $B$, Durrington PN, McElduff $P$, Yarnell $\mathrm{J}$, Azam N, Watt $\mathrm{M}$, et al. Low paraoxonase activity predicts coronary events in the Caerphilly prospective study. Circulation 2003; 107(22): 2775-9.

26. Chandrasekaran S, Gopinath P, Dolia PB. The Gln- Arg192 polymorphism of human paraoxonase 1 gene and the associated phenotype variation is associated with coronary artery disease in south Indian patients. J Evid Based Med Healthc. 2016; 79(3): 4286-92.

27. Tan Y, Liu TR, Hu SW, Tian D, Li C, Zhang JK, et al. Acute coronary syndrome remodels the protein cargo and functions of high -density lipoprotein subfractions. PLoS ONE. 2014; 9(4): e94264. doi:10.1371/journal.pone.0094264.

28. Rahmani M, Raiszadeh F, Allahverdian S, Kiaii S, Navab M, Azizi F. Coronary artery disease is associated with the ratio of apolipoprotein $A-I / B$ and serum concentration of apolipoprotein $B$, but 
not with paraoxonase enzyme activity in Iranian subjects. Atherosclerosis. 2002; 162(2): 381-9.

29. Lakshmy R, Ahmad D, Abraham RA, Sharma M, Vemparala K, Das S, et al. Paraoxonase gene Q192R and L55M polymorphisms in Indians with acute myocardial infarction and association with oxidized low density lipoprotein. Indian J Med Res. 2010; 131: 522-29.

30. Mackness B, Durrington PN, Mackness MI. The paraoxonase gene family and coronary heart disease. Curr Opin Lipidol. 2002; 13(4): 357-62.

31. Liu T, Zhang X, Zhang J, Liang Z, Cai W, Huang $M$, et al. Association between PON1 rs662 polymorphism and coronary artery disease. Eur $\mathrm{J}$ Clin Nutr. 2014; 68(9):1029-35. doi: 10.1038/ ejcn.2014.105.

32. Cozzi L, Campolo J, Parolini M, Maria M, Patrosso $M$, Marocchi $A$, et al. Paraoxonase 1 L55M, Q192R and paraoxonase 2 S311C alleles in atherothrombosis. Mol Cell Biochem 2013; 374 (1-2):233-38. doi: 10.1007/s11010-012-1525-2

33. Sanghera DK, Saha N, Aston CE, Kamboh MI. Genetic polymorphism of paraoxonase and the risk of coronary heart disease. Arterioscler Thromb Vasc Biol. 1997; 17(6):1067-73.

34. Wang X, Fan Z, Huang J, Su S, Yu Q, Zhao J, et al. Extensive association analysis between polymorphism of PON gene cluster with coronary heart disease in Chinese Han population. Arterioscler Thromb Vasc Biol. 2003; 23(2):328-34.

35. Rojas-Garcia AE, Solis-Heredia MJ, Pina-Guzman B, Vega L, Lopez-Carrillo L, Quintanilla Vega B. Genetic polymorphisms and activity of PON1 in Mexican population. Toxicol Appl Pharmacol.
2005; 205(3): 282-89.

36. Kallel A, Sediri Y, Sbai MH, Mourali MS, Feki M, Elasmi $\mathrm{M}$, et al. The paraoxonase $\mathrm{L} 55 \mathrm{M}$ and Q192R gene polymorphisms and myocardial infarction in a Tunisian population. Clin Biochem. 2010; 43(18):1461-63. doi:10.1016/j.clinbiochem. 2010.08. 029.

37. Zama T, Murata M, Matsubara $\mathrm{Y}$, Kawano K, Aoki $\mathrm{N}$, Yoshino $\mathrm{H}$, et al. A 192Arg variant of the human paraoxonase (HUMPONA) gene polymorphism is associated with an increased risk for coronary artery disease in Japanese. Arterioscler Thromb Vasc Biol. 1997; 17(12): 3565-9.

38. Turban S, Fuentes F, Ferlic L, Brugada R, Gotto A, Ballantyne $C$, et al. A prospective study of paraoxonase gene Q/R192 polymorphism and severity, progression and regression of coronary atherosclerosis, plasma lipid levels, clinical events and response to fluvastatin. Atherosclerosis. 2001; 154(3):633-40. doi: 10.1016/S0021-9150 (00)00495-0.

39. Ombres D, Pannitteri G, Montali A, Candeloro A, Saccareccia F, Campagna F, et al. The Gln- Arg 192 polymorphism of human paraoxonase gene is not associated with coronary artery disease in Italian patients. Arterioscler Thromb Vasc Biol. 1998; 18(10):1611-6.

40. Shekhanawar M, Shekhanawar SM, Krisnaswamy D, Indumati V, Satishkumar D, Vijay V, et al. The role of 'Paraoxonase-1 Activity' as an antioxidant in coronary artery disease. J Clin Diagn Res. 2013; 7(7): 1284-7.

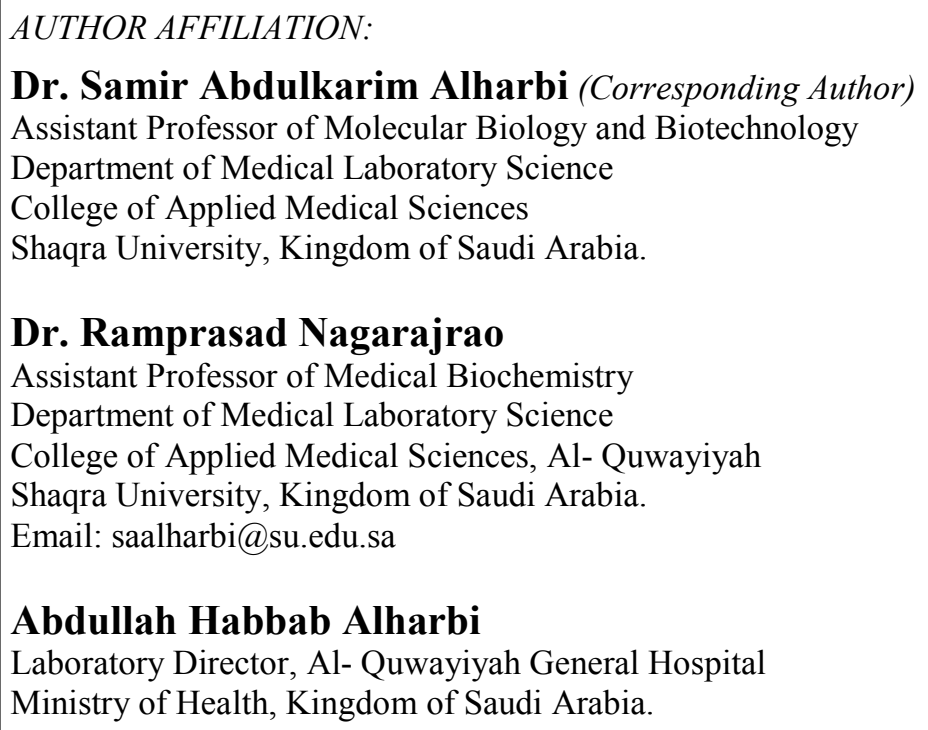

